PLANNING RESEARCH 



\title{
PLANNING RESEARCH
}

\author{
A CONCISE GUIDE FOR \\ THE ENVIRONMENTAL AND \\ NATURAL RESOURCE SCIENCES
}

\section{John C. Gordon}

Yale University Press / New Haven and London 
The following sources have been excerpted with permission: D. E. Koshland, "Two Plus Two Equals Five" (Editorial), Science 247, no. 4949 (1990): 1381, Copyright (c) 1990 AAAS; and T. S. Kuhn, The Structure of Scientific Revolutions, 2nd ed. (Chicago: University of Chicago Press, 1970), Copyright ( $\odot$ 1962, 1970 by the University of Chicago.

Published with assistance from the Louis Stern Memorial Fund.

Copyright (C) 2007 by Yale University.

All rights reserved.

This book may not be reproduced, in whole or in part, including illustrations, in any form (beyond that copying permitted by Sections 107 and 108 of the U.S. Copyright Law and except by reviewers for the public press), without written permission from the publishers.

Designed by Mary Valencia.

Set in Minion and Gill Sans by The Composing Room of Michigan, Inc.

Printed in the United States of America by Vail-Ballou Press, Binghamton, New York.

Library of Congress Cataloging-in-Publication Data

Gordon, J. C. (John C.), 1939-

Planning research : a concise guide for the environmental and natural resource sciences / John C. Gordon.

p. cm.

Includes bibliographical references and index.

ISBN: 978-0-300-12007-3 (clothbound : alk. paper)

ISBN: 978-0-300-12006-6 (pbk. : alk. paper)

1. Environmental sciences-Research. 2. Environmental sciences-Experiments.

I. Title.

GE70.G695 2007

$363.7^{\prime} 0072-\mathrm{dc} 22$

2006026960

A catalogue record for this book is available from the British Library.

The paper in this book meets the guidelines for permanence and durability of the Committee on Production Guidelines for Book Longevity of the Council on Library Resources.

$\begin{array}{lllllllllll}10 & 9 & 8 & 7 & 6 & 5 & 4 & 3 & 2 & 1\end{array}$ 